\title{
EFECTO DE LA DOSIS DE ECG EN OVEJAS TRATADAS CON MAP SOBRE LA INDUCCION DE ESTRO Y OVULACION FUERA DE LA EPOCA DE SERVICIO
}

\author{
Gapel, C..$^{1} ;$ Althaus, R. ${ }^{1}$ \& Sosa, J. ${ }^{1}$
}

\begin{abstract}
RESUMEN
En los últimos años, la ovinocultura, ha tenido un pequeño resurgimiento por tratarse de una alternativa económicamente interesante en la explotación animal, especialmente por la producción de carne para consumo humano y lana por su demanda en los mercados internos y externos. La inducción de estro y ovulación fuera de la temporada reproductiva tiene como objetivo fundamental evaluar el comportamiento sexual de la oveja. La utilización de esponjas vaginales impregnadas con acetato de medroxiprogesterona ha demostrado ser un método eficaz en la sincronización de los ciclos estrales en los ovinos. Así mismo, el uso conjunto de esponjas vaginales y gonadotrofina corionica equina han aumentado los índices de preñez y parición en majadas con servicio natural durante el otoño. Por ello, en el presente trabajo se comparó la utilización en el ovino de dos diferentes dosis de gonadotrofina corionica equina para la inducción de estro y ovulación extemporánea en el período primavera-verano. Se concluye que la utilización de esponjas impregnadas en medroxiprogesterona para la indución del estro y el uso de dosis reducidas (160 UI/oveja) de gonadotrofina corionica equina para la ovulación de ovinos de raza Corriedales es un método favorable para el logro de una gestación fuera de la época habitual del parto.
\end{abstract}

Palabras claves: ovinos, estro, ovulación, preñez, sincronización.

\section{SUMMARY}

\section{Effect of eCG dose in sheep treated with MAP on the oestrus and ovulation outside mof the breeding season.}

During the last years, ovine exploitation has regained importance in Argentine, both for meat production for local consumption and wool production for local and foreing markets. The oestrus induction and ovulation out the reproductive season has as main objetive to evakuate the sexual behavior of sheep. The use of vaginal sponges impregnated with medroxiprogesterona acetate has demonstrated to be an effective method for the synchronization of ewe sexual cycle. Likewise, the combined use of vaginal sponges and equine corionic gonadotropin have increased pregnancy

1.- Instituto de Reproducción Animal. Cátedra de Teriogenología, Facultad de Ciencias Veterinarias, UNL. Kreder 2805. (3080) Esperanza, provincia de Santa Fe. E-mail: cgapel@fcv.unl.edu.ar Manuscrito recibido el $1^{\circ}$ de marzo de 2004 y aceptado para su publicación el 14 de junio de 2004 . 
indexes and calving and natural service during the autumn. In this study, the use in Corriedale ewes of two different doses of equine corionic gonadotropin for oestrus induction and untimely ovulation in spring-summer period was evaluated. It was concluded that use of sponges impregnated in medroxiprogesterone for oestrus inductión and of reduced dose (160 UI/ewes) of equine corionic gonadotropin for ovulation is a favorable method for achieving pregnancy out of habitual calving season.

Key words: ovine, oestrus, ovulation, pregnancy. 